\title{
A new stability-indicating RP-HPLC method for the determination of dicyclomine hydrochloride and dimethicone combination in tablet dosage forms
}

\author{
J. Saroja ${ }^{1,2}$, Anantha Lakshmi P.V. ${ }^{1 *}$, Y. Rammohan ${ }^{2}$ and D. Divya Reddy ${ }^{2}$
}

\begin{abstract}
Background: We describe a "stability-indicating liquid chromatography" technique for the estimation of dimethicone (DEC) and dicyclomine hydrochloride (DEH) in the established tablet formulations. Individual quantification of DEH and DEC was reported. But simultaneous quantification of DEH and DEC was lacking. DEH and DEC were analysed on an "XTerra $C_{18}$ column $(250 \mathrm{~mm} \times 4.6 \mathrm{~mm}, 5 \mu \mathrm{m})$ " with the mobile phase solvent run isocratically with $0.1 \mathrm{M} \mathrm{K}_{2} \mathrm{HPO}_{4}$-acetonitrile $(55: 45, \mathrm{v} / \mathrm{v})$ on a flow speed of $1.0 \mathrm{~mL} / \mathrm{min}$.
\end{abstract}

Results: The chromatographic run period for the DEC and DEH assay was $6.0 \mathrm{~min}$ with retention times of 2.134 and 2.865 min, respectively. The method was validated for accuracy (99.453 to $100.417 \%$ and 99.703 to $100.303 \%$ recovery values for DEH and DEC, respectively), precision (RSV value $0.135 \%$ for $\mathrm{DEC}$ and $0.171 \%$ for $\mathrm{DEH}$ ), linearity (5-15 $\mu \mathrm{g} / \mathrm{mL}$ for DEH and $20-60 \mu \mathrm{g} / \mathrm{mL}$ for DEC), selectivity (no hinderance from excipients) and specificity (no hinderance from degradants) recovery.

Conclusion: The developed stability-indicating liquid chromatography process was well applied to established tablet formulations.

Keywords: Dicyclomine hydrochloride, Dimethicone, Stability indicating, Fixed formulation, Analysis

\section{Background}

Dicyclomine hydrochloride (DEH) is an artificial analogue of acetylcholine with anticholinergic and antimuscarinic activities [1]. Gastrointestinal disorders including irritable bowel syndrome and acidic peptic disorder have been managed with DEH [2, 3]. Dimethicone (DEC) is a polyorganosiloxane and an anti-flatulence/anti-flatulence medication which collapses gas bubbles and facilitates free passing of gas [4]. The DEH and DEC fixed-dose formulation was available as oral drops [5], capsule [6], suspension

\footnotetext{
* Correspondence: pvanantha.ou@gmail.com;

ananthaprasad2003@osmania.ac.in

'Department of Chemistry, University College of Science, Osmania University, Hyderabad 500007, India

Full list of author information is available at the end of the article
}

[7] and tablet [8]. Structures of DEH and DEC are provided in Fig. 1.

Pharmaceutical analysis was often performed out to verify that the drug substance or medication satisfies the two most critical attributes of quality: safety and effectiveness [9]. Manufacturing corporations need both qualitative including quantitative studies to guarantee that its raw materials fulfil the requisites and that the finished material is of high quality. DEH quantification in tablet formulation (by UV spectrophotometry, colorimetry and voltammetry) [10-12] and in milk, serum and urine (by potentiometry and voltammetry) $[12,13]$ was described. DEC quantification in capsule and tablet formulations (by HPLC and infrared spectroscopy) [14, 15] was published. Quantification of DEH in blend with other drugs using UV spectroscopy [16], HPTLC [17] and 

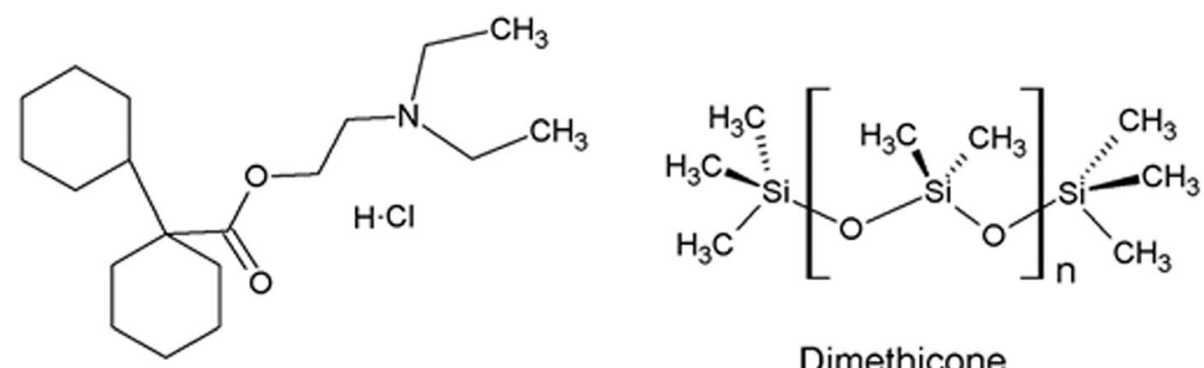

Dimethicone

Dicyclomine hydrochloride

Fig. 1 Structures of the chosen drugs

HPLC [18-24] was also reported. HPLC quantification of DEC in blend with other drugs was also described [25]. Analytical method for DEH and DEC simultaneous quantification was lacking. The main goal of this study was to concurrently analyse the content of DEH and DEC in tablet formulations employing the developed and authenticated "stability-indicating liquid chromatography" (SILC) method. There seems to be no published analytic method for evaluating the content of DEH and DEC in the tablet formulations, to the fullest of our awareness. The uniqueness of the proposed SILC method is that this is the first analysis tool reported for the simple, accurate, sensitive and precise measurement of the DEH and DEC content in tablet formulations.

\section{Methods}

\section{Instruments}

Chromatographic analysis of DEH and DEC was performed employing "Waters HPLC system" furnished with quaternary pump, autosampler, column oven and degasser. UV spectrometric detection operated at 265 $\mathrm{nm}$ was used for DEH and DEC detection and quantitation. Hardware regulation, data acquisition and management were done using "Waters Empower 2" software.

\section{Pure samples}

Reference standards of DEH (99.8\% purity) and DEC ( $98.4 \%$ purity) were gifted by "Rainbow Pharma Training Labs", Hyderabad.

\section{Formulations}

Colicare Tablets ("Omega Pharmaceuticals Pvt Ltd", Chennai) with labelled content of DEH $10 \mathrm{mg}$ and DEC $40 \mathrm{mg}$ were analysed employing the developed and authenticated SILC method.

\section{Chemicals and reagents}

$\mathrm{K}_{2} \mathrm{HPO}_{4}, \mathrm{H}_{2} \mathrm{O}_{2}, \mathrm{HCl}$ and $\mathrm{NaOH}$ of analytical grade were from "Finar Chemicals Limited", Ahmedabad; acetonitrile and Millipore water of chromatography grade were purchased from "Merck India limited", Mumbai, and "Loba chemicals limited", Mumbai, respectively.

\section{SILC method conditions}

"XTerra C18 column $(250 \times 4.6 \mathrm{~mm}, 5 \mu \mathrm{m})$ " was applied for chromatographic separation of DEH and DEC using 0.1 $\mathrm{N} \mathrm{K}_{2} \mathrm{HPO}_{4}$ (55\% vol. ratio; $\left.\mathrm{pH} 4.5\right)$ and acetonitrile (45\% vol. ratio) in an isocratic elution mode. Separation of DEH and DEC was done at a stream rate of $1.0 \mathrm{~mL} / \mathrm{min}$ with an injection volume of $10 \mu \mathrm{L}$ with column warmth of $27^{\circ} \mathrm{C}$.

\section{Stock DEH and DEC solution}

Quantities equal to $40 \mathrm{mg}$ DEC and $10 \mathrm{mg}$ DEH reference standards were appropriately measured and properly transferred to the $100-\mathrm{mL}$ flask, and $40 \mathrm{~mL}$ mobile phase was introduced to the same flask. The solution was well shaken and flask volume was completed with the same mobile phase to achieve $400 \mu \mathrm{g} / \mathrm{mL}$ DEC and $100 \mu \mathrm{g} / \mathrm{mL}$ DEH.

\section{Working DEH and DEC solution}

The working DEH and DEC solutions were prepared by appropriate dilution of their formerly prepared stock $\mathrm{DEH}$ and DEC solution $(400 \mu \mathrm{g} / \mathrm{mL}$ DEC and $100 \mu \mathrm{g} / \mathrm{mL}$ DEH) with the mobile phase solvent to obtain a $10-\mathrm{mL}$ working solution of $40 \mu \mathrm{g} / \mathrm{mL}$ DEC and $10 \mu \mathrm{g} / \mathrm{mL}$ DEH.

\section{Calibration curve}

Quantity ranges covering 5 to $15 \mu \mathrm{g} / \mathrm{mL}$ for $\mathrm{DEH}$ and 20 to $60 \mu \mathrm{g} / \mathrm{mL}$ for DEC were made from stock DEH and DEC solution $(400 \mu \mathrm{g} / \mathrm{mL}$ DEC and $100 \mu \mathrm{g} / \mathrm{mL}$ DEH) using the mobile phase solvent. The solutions were evaluated using the SILC technique proposed. Calibration curves were prepared with a regression line equation to map each analyte's peak area against its concentrations.

\section{DEH and DEC content evaluation in tablets}

Ten Colicare tablets containing a specific of DEH (10 $\mathrm{mg} /$ tablet) and DEC (40 mg/tablet) were taken and were crushed to a finer powder with the pestle and mortar. A 
weighed quantity of the tablet formulation crushed powder, corresponding to $10 \mathrm{mg}$ of DEH and $40 \mathrm{mg}$ of DEC, was transferred properly to a $100-\mathrm{mL}$ flask. Forty milliliters of mobile phase was introduced to the same flask and was sonicated for nearly $20 \mathrm{~min}$ and then filtrated using Whatman no. 1 paper. The flask volume was completed with the same mobile phase to achieve $40 \mu \mathrm{g} / \mathrm{mL}$ DEC and $10 \mu \mathrm{g} / \mathrm{mL}$ DEH. The sample for analysing Colicare tablets was made ready by diluting an aliquot $(1 \mathrm{~mL})$ of tablet formulation sample to $10 \mathrm{~mL}$ with the mobile phase. The tablet formulation test solution was evaluated using the SILC technique proposed.

\section{Forced degradation study}

Forced degradation tests were made on tablet formulation samples of $400 \mu \mathrm{g} / \mathrm{mL}$ DEC and $100 \mu \mathrm{g} / \mathrm{mL}$ DEH concentrations under "ICH Q1A (R2)" given conditions [26].

Sonicating tablet formulation samples $(10 \mathrm{~mL})$ at 27 ${ }^{\circ} \mathrm{C}$ in $0.1 \mathrm{~N} \mathrm{HCl}(10 \mathrm{~mL})$ for $30 \mathrm{~min}$ and in $0.1 \mathrm{~N} \mathrm{NaOH}$ $(10 \mathrm{~mL})$ for $30 \mathrm{~min}$ were used for degradation tests in acid and base stresses, respectively. Peroxide facilitated oxidation was studied by exposing the tablet formulation sample $(10 \mathrm{~mL})$ to $30 \% \mathrm{H}_{2} \mathrm{O}_{2}(10 \mathrm{~mL})$ for $30 \mathrm{~min}$ at 27 ${ }^{\circ} \mathrm{C}$ in the dark. Photolytic degradation was executed by exposing the tablet formulation crushed powder, corresponding to $10 \mathrm{mg}$ of $\mathrm{DEH}$ and $40 \mathrm{mg}$ of DEC, to the sunlight directly for $24 \mathrm{~h}$. Similarly, for thermal stress, the tablet formulation crushed powder was exposed at $105^{\circ} \mathrm{C}$ for $30 \mathrm{~min}$ in the oven.

Each sample was properly diluted by the mobile phase at the end of exposures to acid, $\mathrm{H}_{2} \mathrm{O}_{2}$ and base, to achieve an ultimate amount of $40 \mu \mathrm{g} / \mathrm{mL}$ DEC and 10 $\mu \mathrm{g} / \mathrm{mL} \mathrm{DEH}$. The solutions from the tablet formulation crushed powder exposed to sunlight and dry heat were made as portrayed in the section "DEH and DEC content evaluation in tablets". All the sample solutions were evaluated using the SILC technique proposed.

\section{Results}

SILC method development

Until an optimal response and peak shape for DEC and DEH were obtained, the column and mobile phase solvents were optimised. Columns examined include $\mathrm{YMC} \mathrm{C}_{18}$, Thermo $\mathrm{C}_{18}$, Waters $\mathrm{C}_{18}$ and XTerra $\mathrm{C}_{18}$. Solvent combinations investigated include $0.1 \%$ phosphoric acid-methanol and $0.1 \mathrm{M} \mathrm{K} \mathrm{K}_{2} \mathrm{HPO}_{4}$-acetonitrile. Optimal response and symmetrical peak shapes for DEC and DEH were achieved with an "XTerra $\mathrm{C}_{18}$ column $(250 \mathrm{~mm} \times$ $4.6 \mathrm{~mm}, 5 \mu \mathrm{m}$ )" having column slot temperature of $25^{\circ} \mathrm{C}$ using $0.1 \mathrm{M} \mathrm{K}_{2} \mathrm{HPO}_{4}, \mathrm{pH} 4.5$-acetonitrile $(55: 45, \mathrm{v} / \mathrm{v})$ as mobile phase with isocratic flow type run of $1.0 \mathrm{~mL} / \mathrm{min}$. UV detection with $265 \mathrm{~nm}$ setting was found as the best fit for an optimal peak response and to quantity DEH and DEC. The chromatographic run period for the DEC and DEH assay was $6.0 \mathrm{~min}$ with retention times of 2.134 and 2.865 min observed for DEH and DEC, respectively (Fig. 2).

\section{Validation}

The proposed SILC method was validated under "ICH Q2 (R1)" given conditions [27].

\section{System suitability}

For this assessment, DEC $(40 \mu \mathrm{g} / \mathrm{mL})$ and DEH $(10 \mu \mathrm{g} /$ $\mathrm{mL}$ ) working solutions were infused six times to report the specifications of system suitability. Table 1 outlines the reports of system suitability for the assessment of DEC and DEH combination.

\section{Selectivity}

Mobile phase blank, working DEC $(40 \mu \mathrm{g} / \mathrm{mL})$ and DEH $(10 \mu \mathrm{g} / \mathrm{mL})$ solution and tablet DEC $(40 \mu \mathrm{g} / \mathrm{mL})$ and DEH $(10 \mu \mathrm{g} / \mathrm{mL})$ solution were analysed with the SILC technique proposed to ascertain the selectivity of the established SILC method. In order to track interference

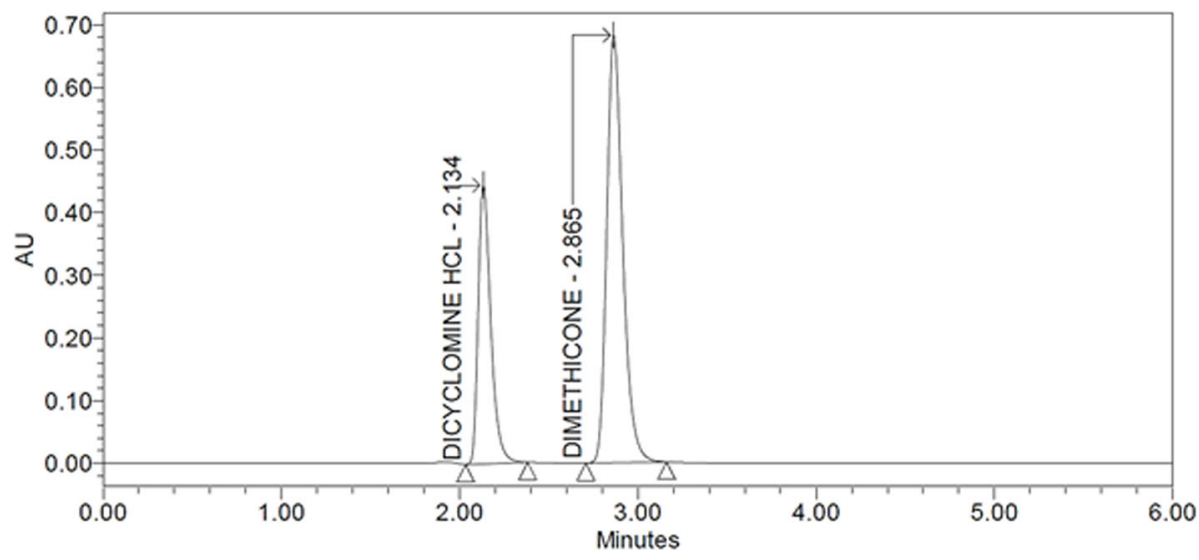

Fig. 2 DEH and DEC chromatogram with the optimized SILC method 
Table 1 DEC and DEH system suitability

\begin{tabular}{|c|c|c|c|c|c|c|c|c|}
\hline Values & $\operatorname{ReT}$ & $\operatorname{ReA}$ & $\operatorname{ReS}$ & PCS & TF & $\mathrm{K}^{\prime}$ & HETP & $a^{\prime}$ \\
\hline \multicolumn{9}{|c|}{ Dicyclomine hydrochloride } \\
\hline $\mathrm{Avg}^{\mathrm{a}}$ & 2.127 & 2173795 & - & 4477 & 1.436 & 1.127 & 0.056 & Avg $^{a} 1.648$ \\
\hline SV & 0.0081 & 5667.4136 & - & 39.8535 & 0.0089 & 0.0079 & 0.0005 & \\
\hline RSV & 0.381 & 0.261 & - & 0.890 & 0.623 & 0.701 & 0.887 & SV 0.0039 \\
\hline \multicolumn{9}{|c|}{ Dimethicone } \\
\hline $\operatorname{Avg}^{a}$ & 2.858 & 4249950 & 4.920 & 4954 & 1.294 & 1.858 & 0.050 & RSV 0.237 \\
\hline SV & 0.0088 & 7331.8554 & 0.0141 & 30.4844 & 0.0055 & 0.0093 & 0.0003 & \\
\hline RSV & 0.309 & 0.173 & 0.287 & 0.615 & 0.423 & 0.499 & 0.636 & \\
\hline
\end{tabular}

SV standard variation, $R S V$ relative standard variation, $R e T$ retention time, ReA response area, ReS resolution, $P C S$ plate counts, $T F$ tailing factor, $K^{\prime}$ capacity factor, HETP height equivalent to theoretical plates, $a^{\prime}$ selectivity factor

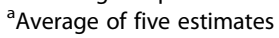

from mobile phase solvents and tablet excipients at the retention times of DEC and DEH, the chromatograms of the related solutions were evaluated (Fig. 3).

\section{Linearity}

The detector responses for DEH and DEC have been computed to be linear over the $5-$ to $15-\mu \mathrm{g} / \mathrm{mL}$ and $20-$ to $60-\mu \mathrm{g} / \mathrm{mL}$ ranges, respectively. The linearity of the SILC technique proposed was assessed by its calculated coefficient of determination value, slope value and intercept value. The linearity regression equation portrayed them as:

$$
\begin{aligned}
& y=217520.92 x-18853.6 \text { and" } R^{2 " v a l u e ~}=0.99998 \text { for } D E H \\
& y=106284.84 x-19926.8 \text { and" } R \text { "value }=0.9995 \text { for } D E C
\end{aligned}
$$

\section{Sensitivity}

Based on the standard deviation value of DEC and DEH responses and the slope of DEC and DEH linearity curves, LOD and LOQ were assessed. The assessed values were $0.017 \mu \mathrm{g} / \mathrm{mL}$ (LOD) and $0.056 \mu \mathrm{g} / \mathrm{mL}$ (LOQ) for DEC and $0.006 \mu \mathrm{g} / \mathrm{mL}$ (LOD) and $0.022 \mu \mathrm{g} /$ $\mathrm{mL}$ (LOQ) for DEH.
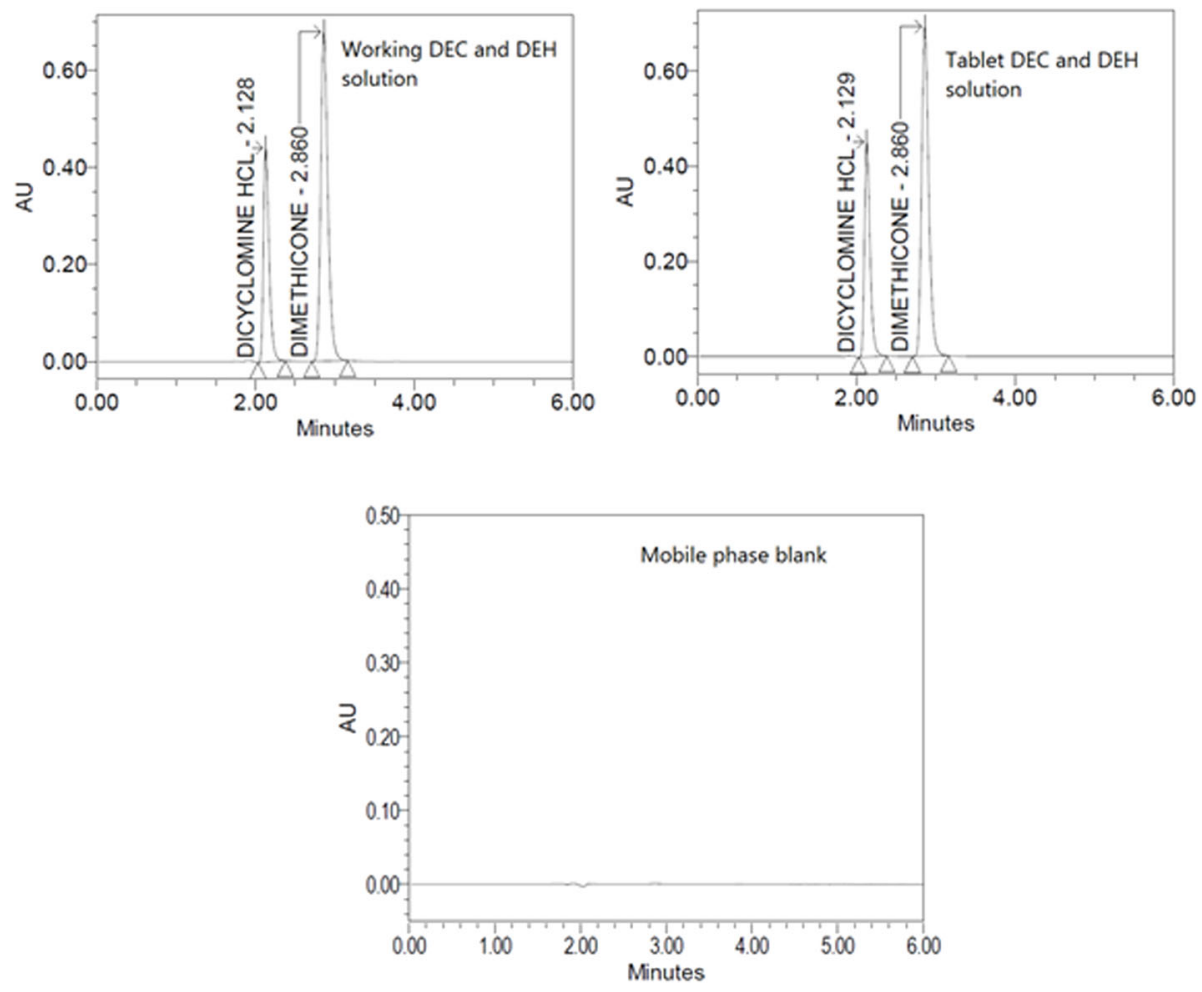

Fig. 3 Selectivity evaluating chromatograms 

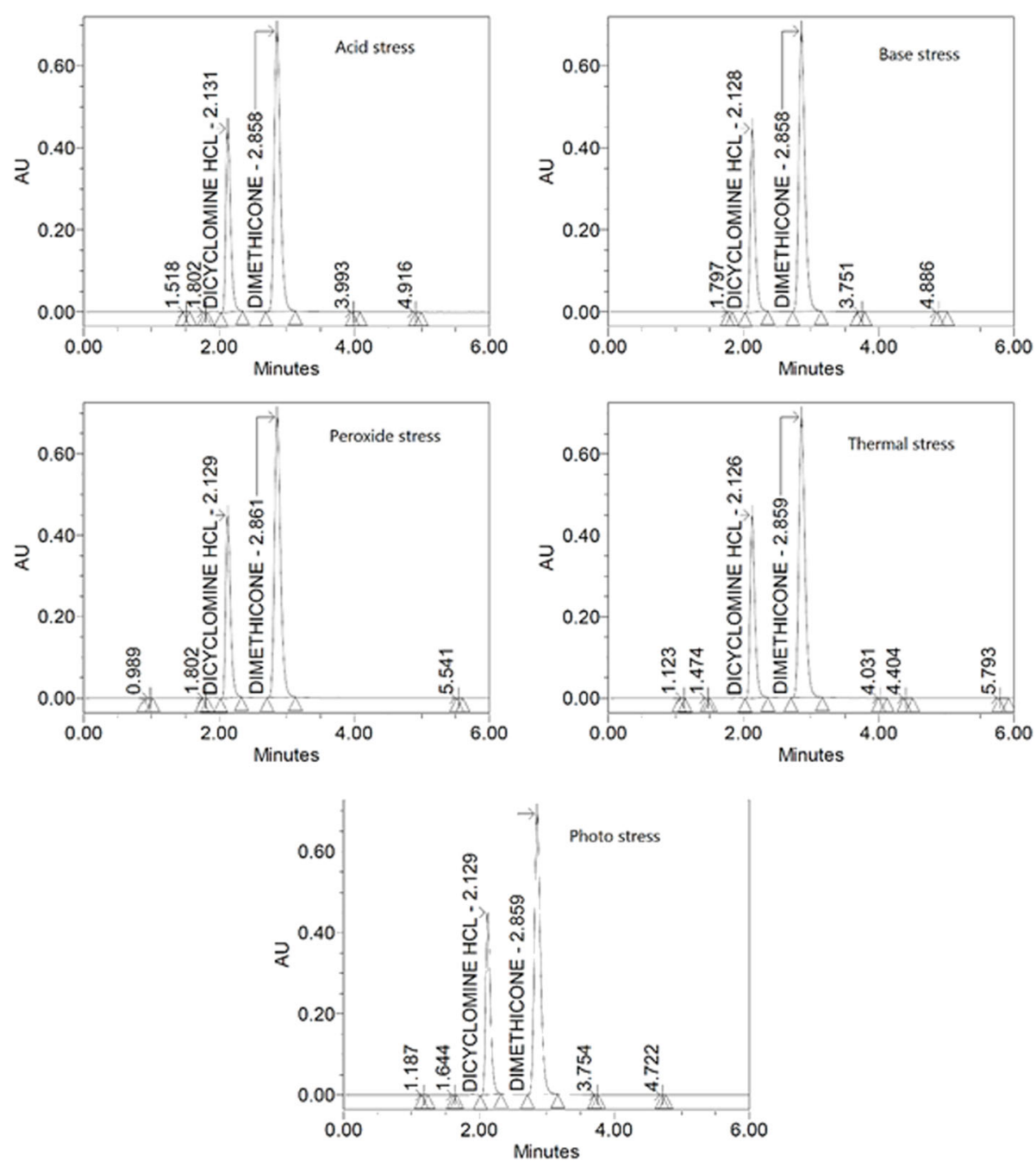

Fig. 4 Specificity evaluating chromatograms

\section{Precision}

The precision of the SILC technique proposed was verified by injecting six DEC $(40 \mu \mathrm{g} / \mathrm{mL})$ and $\mathrm{DEH}$ $(10 \mu \mathrm{g} / \mathrm{mL})$ replicates of the working sample. The values achieved for the six replicates yield a DEC peak area RSV of $0.135 \%$ and a DEH peak area RSV of $0.171 \%$.

\section{Accuracy}

The accuracy of the SILC technique proposed was tested by injecting three spiked tablet sample solutions with DEC and DEH reference standards and analysed in three replicates at three separate concentration scales. The spiked values were $19.80 \mu \mathrm{g} / \mathrm{mL}$ DEC and $4.95 \mu \mathrm{g} / \mathrm{mL}$ $\mathrm{DEH}$ at $50 \%$ level, $39.60 \mu \mathrm{g} / \mathrm{mL}$ DEC and $9.90 \mu \mathrm{g} / \mathrm{mL}$ $\mathrm{DEH}$ at $100 \%$ level and $59.40 \mu \mathrm{g} / \mathrm{mL} \mathrm{DEC}$ and $14.85 \mu \mathrm{g} /$ $\mathrm{mL} \mathrm{DEH}$ at $150 \%$ level. In Table 3 , the recoveries of DEC and DEH are provided.

\section{Robustness}

For this assessment, DEC $(40 \mu \mathrm{g} / \mathrm{mL})$ and DEH $(10 \mu \mathrm{g} /$ $\mathrm{mL}$ ) working solutions were evaluated after implementing the variables to the optimised SILC process. For robustness, the variables deemed include:

- Influence of $\mathrm{pH}$ in the mobile phase $( \pm 0.2)$

- Influence of acetonitrile in the mobile phase $( \pm 5 \%)$

- Influence of wave length $( \pm 2 \mathrm{~nm})$

- Influence of flow rate $( \pm 10 \%)$

- Influence of column temperature $\left( \pm 2{ }^{\circ} \mathrm{C}\right)$

Table 2 DEC and DEH precision

\begin{tabular}{lll}
\hline Values & DEC & DEH \\
\hline Avg $^{\text {a }}$ & 4228366 & 2155217 \\
SV & 5691.0040 & 3680.2056 \\
RSV & 0.135 & 0.171 \\
\hline
\end{tabular}

$S V$ standard variation, $R S V$ relative standard variation

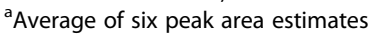


Table 3 Recovery estimates for DEH and DEC

\begin{tabular}{|c|c|c|c|c|}
\hline \multirow[t]{2}{*}{ Drug } & \multirow{2}{*}{$\begin{array}{l}\text { Spike } \\
\text { level } \\
\text { (\%) }\end{array}$} & \multicolumn{2}{|c|}{ Concentration } & \multirow{2}{*}{$\begin{array}{l}\text { Recovered } \\
\text { (\%) }\end{array}$} \\
\hline & & $\begin{array}{l}\text { Spiked drug } \\
(\mu \mathrm{g} / \mathrm{mL})\end{array}$ & $\begin{array}{l}\text { Analysed }^{\mathrm{a}} \text { drug } \\
(\mu \mathrm{g} / \mathrm{mL})\end{array}$ & \\
\hline \multirow[t]{3}{*}{$\overline{\mathrm{DEH}}$} & 50 & 4.950 & 4.923 & 99.453 \\
\hline & 100 & 9.900 & 9.905 & 100.053 \\
\hline & 150 & 14.850 & 14.912 & 100.417 \\
\hline \multirow[t]{3}{*}{ DEC } & 50 & 19.800 & 19.742 & 99.703 \\
\hline & 100 & 39.600 & 39.629 & 100.073 \\
\hline & 150 & 59.400 & 59.581 & 100.303 \\
\hline
\end{tabular}

SV standard variation, RSV relative standard variation

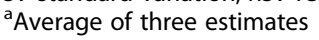

The data obtained (RSD for peak areas) is shown in Table 4.

\section{Specificity}

Forced degradation tests were made on tablet formulation samples of $400 \mu \mathrm{g} / \mathrm{mL}$ DEC and $100 \mu \mathrm{g} / \mathrm{mL}$ DEH concentrations under stress conditions of acid, thermal, base, photo and peroxide. In all stress conditions put in, the DEC and DEH have been noticed to degrade. As an indicator of degradation, detection of supplementary peaks and/or declines in the response area of peaks of DEC and DEH was considered. Table 5 outlines the degradation nature of DEC and DEH under various conditions of stress and displays the related chromatograms in Fig. 4.

The specificity of the SILC technique proposed was investigated by performing a photodiode-array study to examine the integrity of the DEC and DEH peaks and to confirm the purity of DEC and DEH peaks. The peak purity angle measures of DEC and DEH (Table 5) were observed as lesser than their peak purity threshold measures, which means that the DEC and DEH peaks were pure and that stress degradants did not intervene.

\section{Discussion}

The purpose was to establish a method capable of separating and evaluating DEC and DEH efficiently in the shortest feasible run time with reasonable accuracy and reliability. The system was considered to be significantly acceptable for analysing DEC and DEH using the recommended SILC methodology from the data collected (Table 1) [28]. Co-elution of mobile phase solvents and tablet excipients with the main DEC and DEH peak was not observed (Fig. 3). This outcome indicates the SILC method's appropriate selectivity [29]. The outcomes like the coefficient of determination values for DEC and $\mathrm{DEH}$ indicate the SILC method's appropriate linearity [30]. The low findings of LOD and LOQ conveyed the sufficient sensitivity of the SILC technique for the assessment of DEC and DEH [29]. The RSV outcomes less than 2\% (Table 2) indicate the SILC method's appropriate precision [31]. From recovery measures of DEC and DEH (Table 3), it was shown that the SILC approach was accurate [31]. The data obtained (RSD for peak areas) after implementing the variables to the optimised SILC process had appreciably revealed that the SILC technique proposed is robust (Table 4) [32]. The peak purity angle measures of DEC and DEH (Table 5) indicate the SILC method's appropriate specificity and also stability indicating quality [33].

Table 4 Robustness for DEC and DEH assay

\begin{tabular}{|c|c|c|c|c|c|c|c|}
\hline \multirow[t]{2}{*}{ Parameter } & \multirow{2}{*}{$\begin{array}{l}\text { Condition } \\
\text { applied }\end{array}$} & \multicolumn{3}{|l|}{ DEC } & \multicolumn{3}{|l|}{ DEH } \\
\hline & & $\overline{\operatorname{Re} A}$ & SV & $\overline{R S V}$ & $\overline{\operatorname{Re} A}$ & SV & $\overline{\text { RSV }}$ \\
\hline \multirow[t]{3}{*}{ Methanol ratio (\%) } & 45 (opt) & 4258655 & 71394.7813 & 1.682 & 2184928 & 42212.8782 & 1.936 \\
\hline & 40 (varied) & 4308985 & & & 2220846 & & \\
\hline & 50 (varied) & 4168097 & & & 2136719 & & \\
\hline \multirow[t]{3}{*}{ Flow stream (mL/min) } & 1.0 (opt) & 4258655 & 77743.4253 & 1.833 & 2184928 & 30052.5910 & 1.381 \\
\hline & 0.9 (varied) & 4156414 & & & 2142693 & & \\
\hline & 1.1 (varied) & 4308985 & & & 2200846 & & \\
\hline \multirow[t]{3}{*}{$\mathrm{pH}$ value } & 4.5 (opt) & 4311359 & 48299.1214 & 1.121 & 2204010 & 15598.0466 & 0.708 \\
\hline & 4.3 (varied) & 4355115 & & & 2215842 & & \\
\hline & 4.7 (varied) & 4258655 & & & 2184928 & & \\
\hline \multirow[t]{3}{*}{ Detection (nm) } & 265 (opt) & 4258655 & 76387.8855 & 1.794 & 2184928 & 39019.0224 & 1.788 \\
\hline & 263 (varied) & 4333890 & & & 2142622 & & \\
\hline & 267 (varied) & 4181120 & & & 2220565 & & \\
\hline \multirow[t]{3}{*}{ Temperature $\left({ }^{\circ} \mathrm{C}\right)$} & 25 (opt) & 4311359 & 48299.1214 & 1.121 & 2204010 & 15598.0466 & 0.708 \\
\hline & 23 (varied) & 4355115 & & & 2215842 & & \\
\hline & 27 (varied) & 4258655 & & & 2184928 & & \\
\hline
\end{tabular}


Table 5 Degradation and specificity values for DEC and DEH

\begin{tabular}{|c|c|c|c|c|c|}
\hline \multirow[t]{2}{*}{ Stress conditions put in } & \multirow[t]{2}{*}{ Drug } & \multirow{2}{*}{$\begin{array}{l}\text { Peak } \\
\text { response }\end{array}$} & \multirow{2}{*}{$\begin{array}{l}\text { Degradation } \\
\text { (\%) }\end{array}$} & \multicolumn{2}{|c|}{ Peak purity } \\
\hline & & & & Angle & Threshold \\
\hline \multirow[t]{2}{*}{ Control without degradation } & DEH & 2173795 & - & - & - \\
\hline & DEC & 4249950 & - & - & - \\
\hline \multirow[t]{2}{*}{$0.1 \mathrm{~N} \mathrm{HCl}$} & DEH & 1991167 & 8.64 & 0.349 & 0.560 \\
\hline & DEC & 3801785 & 10.9 & 0.266 & 0.458 \\
\hline \multirow[t]{2}{*}{$0.1 \mathrm{~N} \mathrm{NaOH}$} & DEH & 2038512 & 6.41 & 0.264 & 0.659 \\
\hline & DEC & 3951346 & 7.40 & 0.380 & 0.759 \\
\hline \multirow[t]{2}{*}{$30 \%$ peroxide } & DEH & 2064601 & 5.21 & 0.255 & 0.761 \\
\hline & DEC & 3975288 & 6.84 & 0.278 & 0.659 \\
\hline \multirow[t]{2}{*}{$60^{\circ} \mathrm{C}$ Temp. } & DEH & 1933228 & 11.24 & 0.238 & 0.661 \\
\hline & DEC & 3850464 & 9.76 & 0.386 & 0.859 \\
\hline \multirow[t]{2}{*}{ Sunlight } & DEH & 2030208 & 6.79 & 0.354 & 0.763 \\
\hline & DEC & 3908982 & 8.39 & 0.293 & 0.660 \\
\hline
\end{tabular}

\section{Conclusion}

We described a stability-indicating liquid chromatography technique for the estimation of DEC and DEH in the established tablet formulations. According to $\mathrm{ICH}$ criteria, the verification of the recommended approach was carried out and performance evidence for all the criteria evaluated is appropriate. With less processing time, the proposed stability-indicating liquid chromatography approach is simple. This approach could be considered for DEC and DEH quality control testing in the pharmaceutical industry.

\section{Abbreviations}

DEC: Dimethicone; DEH: Dicyclomine hydrochloride; HPLC: High-performance liquid chromatography; RSV: Relative standard variation; UV: Ultraviolet; HPTL C: High-performance thin-layer chromatography; SILC: Stability-indicating liquid chromatography; $\mathrm{K}_{2} \mathrm{HPO}_{4}$ : Dipotassium hydrogen phosphate; $\mathrm{H}_{2} \mathrm{O}_{2}$ : Hydrogen peroxide; $\mathrm{HCl}$ : Hydrochloric acid; $\mathrm{NaOH}$ : Sodium hydroxide; vol.: Volume; ICH: International Conference on Harmonisation; SV: Standard variation; Avg: Average; $R^{2}$ : Correlation coefficient; LOD: Limit of detection; LOQ: Limit of quantification; Temp.: Temperature

\section{Acknowledgements}

The authors thank Rainbow pharma training labs, Hyderabad (Telangana, India), for providing gift samples, dicyclomine hydrochloride and dimethicone and also CMR college of Pharmacy, Medchal, for permitting to avail the facilities for research work.

\section{Authors' contributions}

JS and VR developed and designed the study. JS has performed all the experiments with the help of DDR. JS was responsible for the data acquisition. PVAL supervised the experiment. JS and VR interpreted the data. JS wrote the manuscript. VR and DDR reviewed the data and supported for writing the manuscript. The authors have read and approved the final manuscript.

\section{Funding}

No funding and self-financed.

\section{Declarations}

Ethics approval and consent to participate

Not applicable

\section{Consent for publication \\ Not applicable}

\section{Competing interests}

The authors declare that they have no competing interests.

\section{Author details}

${ }^{1}$ Department of Chemistry, University College of Science, Osmania University, Hyderabad 500007, India. ²Department of Humanities and Sciences, CMR

College of Engineering \& Technology, Hyderabad 501401, India.

Received: 3 March 2021 Accepted: 10 May 2021

Published online: 26 May 2021

\section{References}

1. Dicyclomine hydrochloride, drugbank, Accessed on 26 Jan 2021. Available from: https://go.drugbank.com/salts/DBSALT000698

2. Mark (Taylor) S, Jaime H (2017) Irritable bowel syndrome: a review of treatment options. US Pharmacist 42(12):20-26

3. Lacy BE, Weiser K, De Lee R (2009) The treatment of irritable bowel syndrome. Therap Adv Gastroenterol 2(4):221-238. https://doi.org/10.1177/1 756283X09104794

4. Dimethicone, drugbank, Accessed on 26 Jan 2021. Available from: https:// go.drugbank.com/salts/DBSALT000698

5. Colispas paed oral drops, 1mg.com, Accessed on 26 Jan 2021. Available from: https://www.1 mg.com/drugs/colispas-paed-oral-drops-322338

6. Gastrazine $10 \mathrm{mg} / 40 \mathrm{mg}$ capsule, 1mg.com, Accessed on 26 Jan 2021 Available at: https://www.1mg.com/drugs/gastrazine-10-mg-40-mg-ca psule-150444

7. Spaztus suspension, 1mg.com, Accessed on 26 Jan 2021. Available from: https://www.1mg.com/drugs/spaztus-suspension-261423

8. Colicare 10mg/40mg Tablet, 1mg.com, Accessed on 26 Jan 2021. Available from: https://www.1mg.com/drugs/colicare-10mg-40mg-tablet-303923

9. Peter M, Ladislav N (2015) On the importance of pharmaceutical analysis. Res \& Rev: J Pharma Anal 4(3):13-14

10. Malathi R, Amol D, Jyotsna P (2015) Simple UV spectrophotometric method for estimation of dicyclomine hydrochloride in bulk and tablet formulation. Int J Pharm Res Allied Sci 4(3):109-113

11. Susmithaa K, Chary MT, Venkateshwarlu G (2011) Assay of dicyclomine hydrochloride in pharmaceutical formulations by extractive spectrophotometry. Int J Chem Sci 9(3):1353-1363 
12. Chaitali RR, Anuja SR, Ninad SP, Ashwini KS (2018) Adsorptive stripping voltammetric determination of dicyclomine hydrochloride at a glassy carbon electrode modified with silver decorated $\mathrm{Fe}_{3} \mathrm{O}_{4}$ nanocubes in pharmaceutical and biological samples. Anal Methods 10(12):1441-1451. https://doi.org/10.1039/c8ay00009c

13. Ibrahim $\mathrm{H}$, Hazem YMl, Abu-Shawish M (2005) Potentiometric flow injection analysis of dicyclomine hydrochloride in serum, urine and milk. Anal Chim Acta 532(1):79-88. https://doi.org/10.1016/j.aca.2004.10.046

14. Jadhav JJ, Mungekar S, Jose V, Doshi HA, Gajbe V, Kumar R (2013) A simple and rapid HPLC method for estimation of dimethicone from formulations. Indian drugs 50(3):26-29

15. Torrado G, Garcia-Arieta A, de los Ríos F, Menéndez JC, Santiago T (1999) Quantitative determination of dimethicone in commercial tablets and capsules by Fourier transform infrared spectroscopy and antifoaming activity test. J Pharm Biomed Anal 19(3-4):285-292. https://doi.org/10.1016/ S0731-7085(98)00116-2

16. Wadher SJ, Kalyankar TM, Kshirsagar JR, Anitha K (2017) Simultaneous determination of famotidine and dicyclomine $\mathrm{HCl}$ in combined tablet dosage form by UV-spectrophotometer. Res J Pharm Technol 10(2):408-413. https://doi.org/10.5958/0974-360X.2017.00082.8

17. Sunil RD, Amruta LS, Vidhya KB, Kumudini SR (2011) Validated HPTLC method for nimesulide and dicyclomine hydrochloride in formulation. J Pharm Res 4(7):2288-2290

18. Kumar A, Chawla P, Porwal P, Rawal RK, Anghore D (2018) Development and validation of mefenamic acid, dicyclomine $\mathrm{HCl}$ and pamabrom in marketed formulation by HPLC. Pharm Anal Acta 9(9):1000594. https://doi. org/10.4172/2153-2435.1000594

19. Shah DA, Rana JP, Chhalotiya UK, Baldania SL, Bhatt KK (2014) Development and validation of a liquid chromatographic method for estimation of dicyclomine hydrochloride, mefenamic acid and paracetamol in tablets. Indian J Pharm Sci 76(6):529-534. https://doi. org/10.4103/0250-474X.147238

20. Pandey PK, Patel M, Manigauha A (2020) Simultaneous estimation for dicyclomine $\mathrm{HCl}$ and simethicone in bulk and oral liquid drop formulation: an RP-HPLC method development and validation. Futur J Pharm Sci 6(1):12. https://doi.org/10.1186/s43094-020-00029-x

21. Donda ST, Baviskar VB, Deshmukh PK, Bari SB, Patil PO (2014) Development and validation of a reversed-phase HPLC method for the simultaneous estimation of dicyclomine hydrochloride and famotidine in bulk and tablets. J Chil Chem Soc 59(4):2662-2665. https://doi.org/10.4067/S0717-97072014 000400007

22. Khadge E, Yadav S, Rao J (2017) Reversed phase high performance liquid chromatography method development and validation for simultaneous estimation of dicyclomine hydrochloride, paracetamol and mefenamic acid in bulk and tablet dosage form. Asian J Pharm Clin Res 10:393-397

23. Shrikrishna B, Mulgund S, Ranpise N (2014) Development and validation of RP-HPLC method for simultaneous determination of dicyclomine and mefanamic acid. J Pharm Res 13(1):16-19

24. Sireesha T, Kumari K, Durga sai RV, Naik KS (2014) Development and validation of new analytical methods for the simultaneous estimation of paracetamol and dicyclomine hydrochloride in bulk and pharmaceutical dosage forms by using RP-HPLC and UV methods. World J Pharm Res 3(10): 1584-1602

25. Pal N, Rao AS, Ravikumar P (2016) Stability indicating HPLC method development and validation for simultaneous determination of dimethicone and mosapride in bulk and tablet dosage form. Der Pharmacia Lettre 8(6):1-9

26. International Conference on Harmonisation of technical requirements for registration of pharmaceuticals for human use (2003) ICH Harmonised tripartite guideline. In: Stability testing of new drug substances and products Q1A (R2).

27. International Conference on Harmonisation Expert Working Group (2005) Validation of analytical procedures: text and methodology Q2 (R1).

28. Epshtein NA (2020) System suitability requirements for liquid chromatography methods: controlled parameters and their recommended values (Review). Pharm Chem J 54(5):518-525. https://doi.org/10.1007/s11 094-020-02231-w

29. Marcello L, Dora M, Giuseppe C, Clinio L (2012) Recent HPLC strategies to improve sensitivity and selectivity for the analysis of complex matrices. Instrum Sci Technol 40(2-3):112-137. https://doi.org/10.1080/10739149.2011. 651668
30. Ravisankar P, Navya CN, Pravallika D, Sri DN (2015) A review on step-by-step analytical method validation. IOSR J Pharm 5(10):7-19

31. Betz JM, Brown PN, Roman MC (2011) Accuracy, precision, and reliability of chemical measurements in natural products research. Fitoterapia 82(1):4452. https://doi.org/10.1016/j.fitote.2010.09.011

32. Sergio LCF, Adriana OC, da Thaise SB, Ariana MDSL, Laiana OBS, Walter NLS (2017) Robustness evaluation in analytical methods optimized using experimental designs. Microchem J 131:163-169. https://doi.org/10.1016/j. microc.2016.12.004

33. Soumia B, Fatima H, Saïd B, Bouchaïb B, Souad T, Souad H, Ahmed B, Abdelmjid A (2017) Statistical tools and approaches to validate analytical methods: methodology and practical examples. Int J Metrol Qual Eng 8(9): 1-10. https://doi.org/10.1051/ijmge/2016030

\section{Publisher's Note}

Springer Nature remains neutral with regard to jurisdictional claims in published maps and institutional affiliations.

\section{Submit your manuscript to a SpringerOpen ${ }^{\circ}$ journal and benefit from:}

- Convenient online submission

- Rigorous peer review

- Open access: articles freely available online

High visibility within the field

- Retaining the copyright to your article

Submit your next manuscript at $\boldsymbol{\nabla}$ springeropen.com 